\title{
Treatment of metal-containing effluents from textile-dyeing industries by aquatic macrophytes to improve surface water treatment systems
}

\author{
H. Momtaz ${ }^{1}$, F. Alam ${ }^{2}$, M. A. Ahsan ${ }^{1 *}$, A. K. M. R. Alam ${ }^{3}$, N. Sultana ${ }^{1}$, S. Siraj ${ }^{1}$, \\ M. A. Akbor ${ }^{1}$ and M. M. Rashid ${ }^{1}$ \\ ${ }^{1}$ Analytical Research Division, BCSIR Laboratories, Dhaka \\ ${ }^{2}$ The Science Prove International, Tejgaon, Dhaka \\ ${ }^{3}$ Department of Environmental Sciences, Jahangirnagar University, Savar, Dhaka
}

\begin{abstract}
The present study was carried out to determine the physicochemical parameters of industrial effluents and to find out suitable macrophytes in removing metals from wastewater in order to enhance surface water treatment systems. The effluent samples, effluent free water and aquatic macrophytes were collected from Savar region. Higher values of temperature $\left(56^{\circ} \mathrm{C}\right), \mathrm{pH}(12.32)$, electrical conductivity $(12375$ $\mu \mathrm{S} / \mathrm{cm})$, biochemical oxygen demand $(835 \mathrm{mg} / \mathrm{L})$, total suspended solids $(2187 \mathrm{mg} / \mathrm{L})$, total dissolved solids $(6952 \mathrm{mg} / \mathrm{L})$, turbidity $(89.53$ NTU) and total organic carbon $(421.6 \mathrm{mg} / \mathrm{L})$ were recorded in industrial effluents comparing with control. The lowest concentration of DO in industrial effluents $(0.12 \mathrm{mg} / \mathrm{L})$ was much lower than the control $(5.65 \mathrm{mg} / \mathrm{L})$. The concentration of $\mathrm{Cr}(0.69 \mathrm{mg} / \mathrm{L}), \mathrm{Se}(0.08 \mathrm{mg} / \mathrm{L}), \mathrm{Pb}$ $(0.23 \mathrm{mg} / \mathrm{L})$ and $\mathrm{Cu}(0.71 \mathrm{mg} / \mathrm{L})$ in the effluent exceeded the limit of DOE. Although the concentration of Cd $(0.017 \mathrm{mg} / \mathrm{L}), \mathrm{Li}(0.019 \mathrm{mg} / \mathrm{L})$, $\mathrm{Ni}(0.7 \mathrm{mg} / \mathrm{L})$ and $\mathrm{Zn}(0.38 \mathrm{mg} / \mathrm{L})$ of effluent water were within the limit of DOE, but were much higher than the control water. The cultures of aquatic macrophytes, Eichornia crassipes, Pistia stratoites and Salvinia cucullata using textile-dyeing effluent can efficiently uptake metals from the effluent. The uptake of metals increased with raising effluent concentration in relation to control culture. When cultured in 100\% effluent, Eichornia crassipes, Pistia stratoites and Salvinia cucullata can uptake relatively high amount of Cr, Cd, Cu, Li, $\mathrm{Ni}, \mathrm{Zn}, \mathrm{Co}$, Se and $\mathrm{Pb}$ compared to other two cultures (control, 50\% effluent). At 100\% effluent water, Eichornia crassipes and Pistia stratoites can uptake more than $90 \% \mathrm{Co}$ and $80 \% \mathrm{Se}$ and $\mathrm{Pb}$ with low survival capacity. Salvinia cucullata can efficiently absorb Cr, Cd, Li, Ni and $\mathrm{Pb}$ with long time survival capacity. While individually Pistia stratoites is more effective in absorbing Cu, $\mathrm{Zn}$ and Eichornia crassipes for absorbing $\mathrm{Co}$ and $\mathrm{Pb}$ in order to enhance surface water treatment system.
\end{abstract}

Keywords: Industrial effluents; Metals; Pistia stratiotes L; Eichornia crassipes Mart.; Salvinia cucullata Roxb.; Water quality

\section{Introduction}

The effluents from the most of industries contain toxic elements and directly discharge in the aquatic environment without treatment. The discharges of effluent into an aquatic body can seriously affect its flora, fauna and abiotic components (Goutam, 1992). The aquatic environment is more susceptible to the harmful effects of heavy metal pollution because aquatic flora and fauna are in close and prolonged contact with the soluble toxic elements (Chow, 1968). The increase of industrial activities has aggrevated environmental pollution problems and the deterioration of several aquatic ecosystems with the accumulation of pollutants.

Wastewater treatment is necessary before disposal to prevent any significant undesirable or harmful effect (Pelczar et. al., 1993). Phytoremediation can be defined as "the efficient use of plants to remove, detoxify or immobilize environmental contaminants in a growth matrix (soil, water or sediments) through the biological, chemical or physical activities and process of the plants" (Salati, 1987). Removal of pollutants by aquatic macrophytes involves growing plants in a contaminated matrix, or facilitates immobilization (binding/containment) or degradation (detoxification) of the pollutants and the plants can be subsequently harvested, processed and disposed. The uptake of contaminants in plants occurs primarily through the root system because it provides enormous surface area that absorbs and accumulates the water and nutrients essential for growth along with other non-essential contaminants (Espinoza - Quinones et. al., 2004). The most common metal pollutants are lead, mercury, chromium, iron, copper, manganese, cadmium, arsenic, nickel, aluminium, silver and beryllium. The true water plants such as Eichornia crassipes Mart. has been found capable of uptake metals pollution caused by industrial releases carrying $\mathrm{Cd}, \mathrm{Ni}, \mathrm{Cr}, \mathrm{Pb}$ and the like in water bodies (Akcin et. al., 1994).

*Corresponding author. e-mail: aahsan_61@yahoo.com 
At present Dhaka Water Supply and Sewerage Authority (DWASA) is dependent more on the surface water than the ground water because of over extraction of ground water. By using more chemicals the treatment cost stands high and cannot get pure drinking water. For this reason, the bad quality and odorous water creates different types of water carrying diseases and the health status of city population is becoming threat (Hossain, 2010). Effluent discharges from industry contain high amount of $\mathrm{Cd}, \mathrm{Cr}, \mathrm{Cu}, \mathrm{Pb}, \mathrm{Hg}$, Se and other pollutants which is directly discharged into the surrounding land, agricultural fields, irrigation channels and surface water and finally enter into the river (Dara, 1993 and Sultana et. al., 2003). Aquatic macrophytes such as water hyacinth (Eichornia crassipes), water lettuce (Pistia atratoites), salvinia (Salvinia spp.) and some species of duckweeds (Lemna spp., Spirodella spp., etc.) have been extensively investigated in case of pollutant removal (Espinoza et. al., 2004). They are known to remove metals by surface adsorption and/or absorption and incorporate them into their own system or store them in a bound form (Abbasi and Nipaney, 1993; Russel, 1987). The present study was undertaken to investigate the effectiveness of aquatic macrophytes in removing metals from industrial effluents discharged from textile industries.

\section{Materials and methods}

\section{Collection of effluents and fresh water samples}

The wastewater sample was collected from the point of the Dhaka Export Processing Zone (DEPZ), Savar, Dhaka dur ing dry season (February-March 2011). For comparison, control sample was collected from the wetland of Bangladesh Livestock Research Institute (BLRI), Savar that does not receive any industrial discharge. The sampling was done very cautiously using spot sampling techniques (Gupta, 2005). The high density PVC containers were used for sampling. They were thoroughly cleaned by rinsing with $8 \mathrm{M}$ $\mathrm{HNO}_{3}$ and deionized water followed by repeated washing with water samples so as to avoid contamination (De, 2000). The bottles were kept air tight and labeled properly for identification and some parameters such as $\mathrm{pH}$, conductivity, dissolved oxygen and temperature of the samples were measured on the spot using glass electrode $\mathrm{pH}$ meter, EC meter, DO meter and Thermometer respectively (Gupta, 2005; De, 2000 and Peavy et. al., 1985). Aeration during sampling was avoided as best as possible. A portion of the water samples were acidified for metals analysis.

\section{Collection of aquatic macrophytes}

Aquatic macrophytes were collected from the lakes of Jahangirnagar University campus, because these lakes have no connection with the industrial effluent and the aquatic macrophytes were preserved in the artificial pond in Biological Research Division of Bangladesh Council of Scientific and Industrial Research (BCSIR), Dhaka. A total of 90 plants were collected from fresh water body, among them 20 were Eichornia crassipes, 35 were Pistia stratoites and 35 were Salvinia cucullata. The plants were collected from lake in fully undisturbed conditions and transported to the laboratory. After collection they were kept in fresh water artificial pond (Fig 1). The following aquatic macrophytes were taken as test species (Figs. 2, 3 and 4).

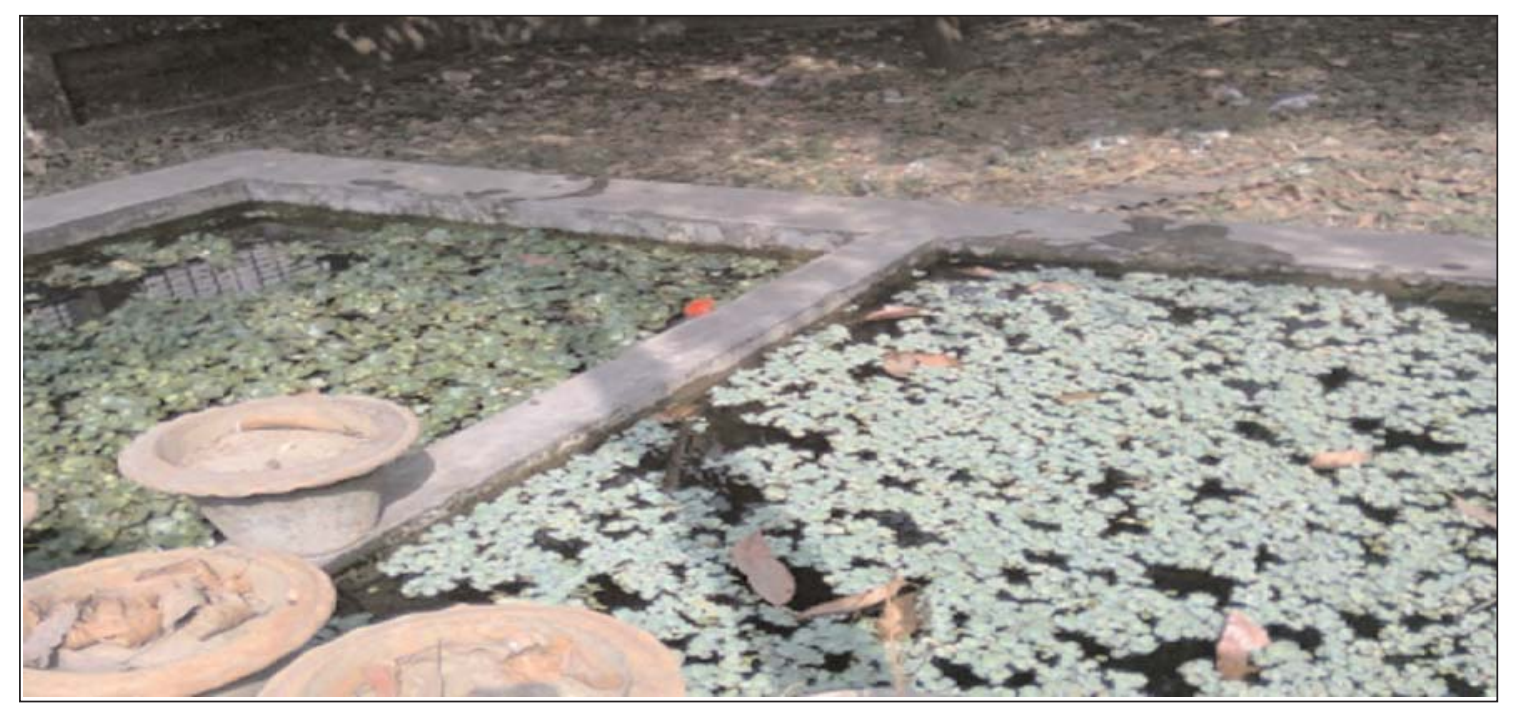

Fig. 1. Preservation of aquatic macrophytes in laboratory pond at natural condition 


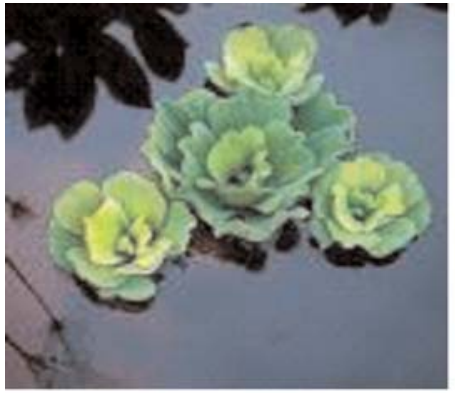

Fig. 2. Pistia stratiotes L.

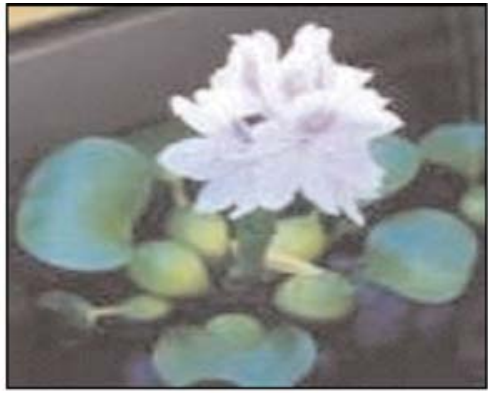

Fig. 3. Eichornia crassipes $\mathrm{M}$.

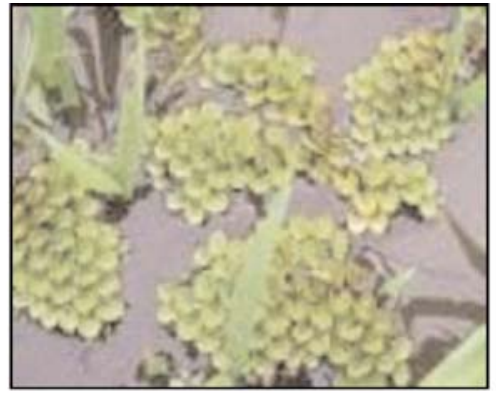

Fig. 4. Salvinia cucullata R.
The physico-chemical analysis was carried out in the Analytical Research Division, BCSIR Laboratories, Dhaka. Physico-chemical parameters such as turbidity was measured by Turbidity meter (Hi C-114), total suspended solids (TSS) and total dissolved solids (TDS) were measured by gravimetric method (APHA, 1976), Biochemical oxygen demand $\left(\mathrm{BOD}_{5}\right)$, was measured by Winkler method (De, 2000) and TOC was analyzed by TOC Analyzer (TOC-V CPN, Shimadzu).

In order to determine the concentration of metals the water samples were digested with $\mathrm{HNO}_{3}$ and plant samples were digested with $\mathrm{HNO}_{3}$ and $\mathrm{HClO}_{4}$ as described in AOAC Official Method 975.03 (APHA, 1976). Then the determinations of metals ( $\mathrm{Cr}, \mathrm{Cd}, \mathrm{Cu}, \mathrm{Li}, \mathrm{Ni}, \mathrm{Zn}, \mathrm{Co}, \mathrm{Se}$ and $\mathrm{Pb}$ ) were performed by Inductively Coupled Plasma Mass Spectrophotometer (VARIAN, Australia).

Uptake of metals from effluent water samples using aquatic macrophytes

Experiments were performed during February to May, 2011. The effluent samples were first taken on a big plastic bowl and allowed to settle for 3 days. After 3 days the precipitate was separated from water samples. Three aquatic macrophytes namely Pistia stratiotes L., Eichornia crassipes Mart. and Salvinia cucullata Roxb. were used for experiments (Fig. 5).

\section{Procedure}

The experiment were conducted in glass jar and in half spherical earthen containers $(50 \mathrm{~cm}$ in diameter) with a working depth of $10 \mathrm{~cm}$, a surface area of $0.5 \mathrm{~m}^{2}$ and a capacity of $20 \mathrm{~L}$ of polluted surface water. In this research, the plants were grown in different percentage $50 \%$, and $100 \%$ of effluents. A control experiment was carried out with effluent free water from control site. Each experiment was repeated three times and the average of the data are reported here. During experiments the phenotypic impacts on test species were recorded everyday. The total treatment period was 30 days. After the experimental period, the metal concentrations in test plant species were determined by Inductively Coupled Plasma Mass Spectroscopy.

\section{Results and discussion}

The physicochemical parameters of wastewater from textiledyeing industries are presented in Table I. The results reveal that the value of temperature $\left(56^{\circ} \mathrm{C}\right), \mathrm{pH}(12.32), \mathrm{EC}(12375$ $\mu \mathrm{s} / \mathrm{cm}), \mathrm{BOD}_{5}(835 \mathrm{mg} / \mathrm{L})$, TSS $(2187 \mathrm{mg} / \mathrm{L})$, TDS $(6952$ $\mathrm{mg} / \mathrm{L})$, turbidity $(89.53)$ and TOC $(421.6 \mathrm{mg} / \mathrm{L})$ are much

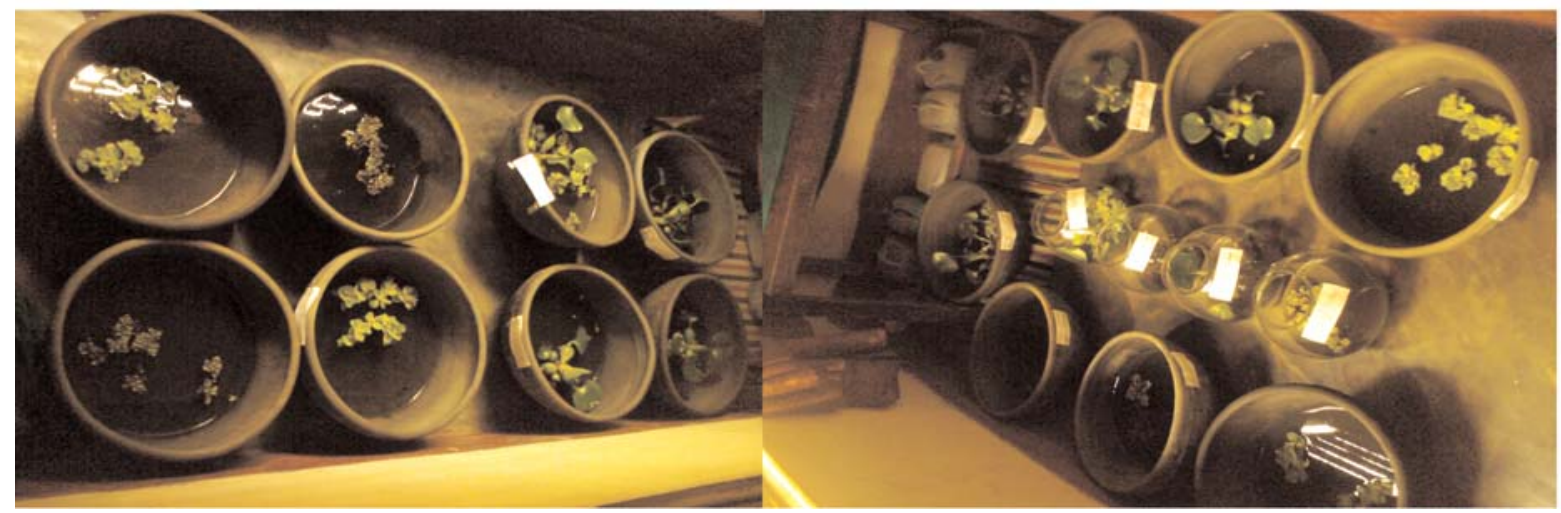

Fig. 5. Experiments for removal of metals with aquatic maccrophytes using different percentage of effluents 
higher in effluents from textile-dyeing than the control water and exceeded the limit of DOE (2003).

The temperature of the effluent $\left(56{ }^{\circ} \mathrm{C}\right)$ was much higher than the limit of DOE $\left(40^{\circ} \mathrm{C}\right)$ but in control water it is within the DOE limit. Excessive $\mathrm{pH}$ is harmful for aquatic life like fish, microorganisms and aquatic plants. Water $\mathrm{pH}$ influences the other properties of waterbody, activity of organisms and potency of toxic substances present in the aquatic environment (Yusuff et. al., 2005; Rouse, 1979). The reported $\mathrm{pH}$ value of the effluent water was 12.32, which exceeds the limit of DOE (6-9) (Table I). In control water, the value of $\mathrm{pH}$ was 6.72 which is within the permissible limit of DOE (6-9) (Table I).

The value of EC of the effluent was found $12375(\mu \mathrm{S} / \mathrm{cm})$ which exceeded the limit of DOE $(1200 \mu \mathrm{S} / \mathrm{cm})$ and indicates that a large amount of ionic substances like sodium, chloride etc are released from textile industry. Such a high value of EC is not suitable for aquatic life and irrigation purposes.

DO in water is essential for aquatic life. Deficiencies of DO in water give rise to odoriferous products of anaerobic decomposition. The value of DO of the textile effluents was $0.12 \mathrm{mg} / \mathrm{L}$, which is much below the limit of DOE (4.5-8). The low DO value of the effluent of the textile mill suggested that this industry was producing a substantial quantity of organic substances, most likely the dyes, which are high oxygen demanding wastes (Emongor et. al., 2005). But in the control site, the value of DO was $5.79 \mathrm{mg} / \mathrm{L}$, which is within the limit of DOE (4.5-8) (Table I).

Biochemical oxygen demand $\left(\mathrm{BOD}_{5}\right)$ is an index of the biodegradable organics present in the system. $\mathrm{BOD}_{5}$ is the quantity of oxygen required by bacteria and other microorganisms during the biochemical degradation and transformation of organic matter present in wastewater under aerobic conditions (Dara, 2002). The value of $\mathrm{BOD}_{5}$ in the studied textile effluent was $835 \mathrm{mg} / \mathrm{L}$ which was quite higher than the limit of DOE $(50 \mathrm{mg} / \mathrm{L})$. Such high value of $\mathrm{BOD}_{5}$ cancause serious damage to aquatic flora and fauna like fish and microorganisms (Kabir et. al., 2002).

Total suspended solids (TSS) present in the effluent relived from textile-dyeing industries was $2187 \mathrm{mg} / \mathrm{L}$, which exceeds the limit of DOE $(150 \mathrm{mg} / \mathrm{L})$. In control water, the value of TSS was $97.5 \mathrm{mg} / \mathrm{L}$ which is within the permissible limit of DOE $(150 \mathrm{mg} / \mathrm{L})$. TSS denotes the suspended impurities present in water. High TSS present in water bodies may block the sunlight required to photosynthesis by the bottom vegetation (Peavy et. al., 1985; Davis and Cornwell, 1998). The high amount of dissolved solids in water increases the water density; it influences osmoregulation of freshwater organisms and reduces solubility of gases. Increased $\mathrm{pH}$ of the sample might have resulted in the dissolution of low molecular mass organic bases originating from dye industries. This also gives rise to higher TDS value (Moore et. al., 1960). As the value of $\mathrm{pH}$ of the wastewater of textile industries was high, the value of TDS (6952 mg/L) was also high which crossed the standard of DOE (Table I).

Turbidity in water is caused by suspended and colloidal matter such as clay, silt, finely divided organic and inorganic matter, and plankton and other microscopic organisms. The turbidity of the textile effluent was 89.53 NTU which exceeded the limit of DOE (10 NTU). High total organic carbon (TOC) value in the textile effluent indicates that high amount of organic substances most likely the organic dyes are used in the textile industry. All the organic wastes undergo degradation and decomposition by bacterial activity in presence of dissolved oxygen (DO). These results in rapid depletion of DO level from the water, which is harmful to aquatic life. When TOC value is high, biochemical oxygen demand $\left(\mathrm{BOD}_{5}\right)$ is also high (Table I).

Table II shows that the content of $\mathrm{Cr}(0.69 \mathrm{mg} / \mathrm{L})$ exceeded the limit of DOE $(0.1 \mathrm{mg} / \mathrm{L})$ in the textile-dyeing effluent whereas in the control water $(<0.01 \mathrm{mg} / \mathrm{L})$ it is within the DOE limit. This result suggested that textile dyeing industries use chromium containing compounds such as chrome agent in dyeing processes. The value of $\mathrm{Se}(0.08 \mathrm{mg} / \mathrm{L}), \mathrm{Pb}$

Table I. Physicochemical parameters of the water sample and its comparison with standards for industrial waste (DOE, 2003)

\begin{tabular}{lccccccccc}
\hline Water & $\begin{array}{c}\text { Temperature } \\
\left({ }^{\circ} \mathrm{C}\right)\end{array}$ & $\mathrm{pH}$ & $\begin{array}{c}\mathrm{EC} \\
(\mu \mathrm{S} / \mathrm{cm})\end{array}$ & $\begin{array}{c}\mathrm{DO} \\
(\mathrm{mg} / \mathrm{L})\end{array}$ & $\begin{array}{c}\mathrm{BOD}_{5} \\
(\mathrm{mg} / \mathrm{L})\end{array}$ & $\begin{array}{c}\mathrm{TSS} \\
(\mathrm{mg} / \mathrm{L})\end{array}$ & $\begin{array}{c}\text { TDS } \\
(\mathrm{mg} / \mathrm{L})\end{array}$ & $\begin{array}{c}\text { Turbidity } \\
(\mathrm{NTU})\end{array}$ & $\begin{array}{c}\text { TOC } \\
(\mathrm{mg} / \mathrm{L})\end{array}$ \\
\hline Effluent & 56 & 12.32 & 12375 & 0.12 & 835 & 2187 & 6952 & 89.53 & 421.6 \\
Control & 25 & 6.72 & 1045 & 5.79 & 8.7 & 97.5 & 1036 & 11.15 & 13.25 \\
DOE $(2003)$ & 40 & $6-9$ & 1200 & $4.5-8$ & 50 & 150 & 2100 & 10 & --- \\
\hline
\end{tabular}


Table II. Metal content of the water sample and its comparison with standards for industrial waste (DOE, 2003)

\begin{tabular}{lcccccccc}
\hline Water & $\begin{array}{c}\mathrm{Cr} \\
(\mathrm{mg} / \mathrm{L})\end{array}$ & $\begin{array}{c}\mathrm{Cd} \\
(\mathrm{mg} / \mathrm{L})\end{array}$ & $\begin{array}{c}\mathrm{Cu} \\
(\mathrm{mg} / \mathrm{L})\end{array}$ & $\begin{array}{c}\mathrm{Li} \\
(\mathrm{mg} / \mathrm{L})\end{array}$ & $\begin{array}{c}\mathrm{Ni} \\
(\mathrm{mg} / \mathrm{L})\end{array}$ & $\begin{array}{c}\mathrm{Zn} \\
(\mathrm{mg} / \mathrm{L})\end{array}$ & $\begin{array}{c}\mathrm{Se} \\
(\mathrm{mg} / \mathrm{L})\end{array}$ & $\begin{array}{c}\mathrm{Pb} \\
(\mathrm{mg} / \mathrm{L})\end{array}$ \\
\hline Effluent & 0.69 & 0.017 & 0.71 & 0.019 & 0.7 & 0.38 & 0.08 & 0.23 \\
Control & $<0.01$ & $<0.01$ & 0.03 & $<0.01$ & 0.01 & 0.14 & 0.006 & $<0.01$ \\
DOE (2003) & 0.1 & 0.05 & 0.5 & --- & 1.0 & 5.0 & 0.05 & 0.1 \\
\hline
\end{tabular}

$(0.23 \mathrm{mg} / \mathrm{L})$ and $\mathrm{Cu}(0.71 \mathrm{mg} / \mathrm{L})$ in the effluent also crossed the limit of DOE $(0.05 \mathrm{mg} / \mathrm{L})$. The concentration of $\mathrm{Cd}, \mathrm{Li}$, $\mathrm{Ni}$ and $\mathrm{Zn}$ of the studied effluent water were within the limit of DOE (2003), but these concentrations were much higher in the effluent water compared to control water. It suggested that the industries mostly use organic dyes and some heavy metal pigment dyes.

The physicochemical parameters of textile-dyeing effluent exceeds the range of DOE (2003) although in control water these were within the limit of DOE (2003) (Table I). The value of most of the metals in wastewater exceeded the limit of DOE (2003). So when test aquatic plant species were grown in effluent water containing metals it may uptake metals from wastewater due to hyper-accumulation.

When P. stratiotes was grown in $50 \%$ and $100 \%$ effluent water the concentration of $\mathrm{Cr}$ were recorded 9.75 and 20.04 ppm, respectively in plant sample and the plants survived 79 and 2-3 days, respectively of growth in effluents of textile industries (Table III, IV). The uptake of Cr by P. stratiotes was higher at $100 \%$ effluent water compared to $50 \%$ and control water and the value exceeded the normal range in plant material (Pendias, 1984) (Table III, IV). When E. crassipes was grown in 50\% and $100 \%$ effluent water, 7.16 and $8.52 \mathrm{ppm}$, respectively of $\mathrm{Cr}$ accumulated in its plant sample and the plant was survived 17-20 and 6-7 days, respectively after growing in effluents (Table III, IV). In both percentage of effluent the content of $\mathrm{Cr}$ in E. crassipes was within the normal range in plant material (Pendias, 1984) but the value was higher than the plant grown in control water $(3.63 \mathrm{ppm})$. The concentration of $\mathrm{Cr}$ was recorded 10.63 and $34.26 \mathrm{ppm}$, respectively in plant sample when $S$. cucullata was grown in $50 \%$ and $100 \%$ effluent water and the plant was survived 22 25 and 7-8 days, respectively of growth in effluents (Table III, IV). The present findings show dissimilarity with the normal range in plant material (Pendias, 1984); and the uptake of $\mathrm{Cr}$ increased with raising the concentration of effluent (Table III, IV).

When P. stratiotes was grown in $50 \%$ and $100 \%$ effluent, the concentrations of $\mathrm{Cd}$ were 0.30 and $0.34 \mathrm{ppm}$, respectively and the plants survived after 7-9 and 2-3 days, respectively

Table III. Removal of some metals by Pistia stratiotes L., Eichornia crassipes M. and Salvinia cucullata R. using 50\% and $100 \%$ textile effluent and its comparison with control test and normal range in plant material

\begin{tabular}{|c|c|c|c|c|c|c|c|c|c|c|}
\hline \multirow{3}{*}{ Metals } & \multirow{2}{*}{\multicolumn{3}{|c|}{ Pistia stratiotes $\mathrm{L}$. }} & \multirow{2}{*}{\multicolumn{3}{|c|}{$\begin{array}{l}\text { Eichornia crassipes } \mathrm{M} \text {. } \\
\text { Metal concentration }\end{array}$}} & \multirow{2}{*}{\multicolumn{3}{|c|}{ Salvinia cucullata $\mathrm{R}$. }} & \multirow{3}{*}{$\begin{array}{c}\text { Normal range } \\
\text { in plant } \\
\text { material } \\
\text { (ppm) }\end{array}$} \\
\hline & & & & & & & & & & \\
\hline & $\begin{array}{l}\text { control } \\
\text { water } \\
(\mathrm{ppm})\end{array}$ & $\begin{array}{l}50 \% \\
\text { effluents } \\
(\mathrm{ppm})\end{array}$ & $\begin{array}{l}100 \% \\
\text { water } \\
(\mathrm{ppm})\end{array}$ & $\begin{array}{l}\text { control } \\
\text { effluents } \\
\text { (ppm) }\end{array}$ & $\begin{array}{c}50 \% \\
\text { water } \\
(\mathrm{ppm})\end{array}$ & $\begin{array}{l}100 \% \\
\text { effluents } \\
(\mathrm{ppm})\end{array}$ & $\begin{array}{l}\text { control } \\
\text { water } \\
(\mathrm{ppm})\end{array}$ & $\begin{array}{l}50 \% \\
\text { effluents } \\
(\mathrm{ppm})\end{array}$ & $\begin{array}{l}100 \% \\
\text { effluents } \\
\text { (ppm) }\end{array}$ & \\
\hline $\mathrm{Cr}$ & 7.48 & 9.75 & 20.04 & 3.63 & 7.16 & 8.52 & 7.27 & 10.63 & 34.26 & $0.03-15$ \\
\hline $\mathrm{Cd}$ & 0.20 & 0.30 & 0.34 & 0.12 & 0.17 & 0.28 & 0.16 & 0.32 & 0.42 & $0.2-0.8$ \\
\hline $\mathrm{Cu}$ & 22.05 & 45.2 & 64.32 & 18.28 & 23.88 & 27.72 & 27.28 & 42.21 & 52.02 & $20-100$ \\
\hline $\mathrm{Li}$ & 3.80 & 7.41 & 9.52 & 1.38 & 1.94 & 2.81 & 2.53 & 9.92 & 21.36 & ---- \\
\hline $\mathrm{Ni}$ & 5.40 & 5.86 & 8.32 & 3.81 & 3.90 & 4.92 & 4.77 & 8.27 & 15.35 & $0.02-5$ \\
\hline $\mathrm{Zn}$ & 47.1 & 64.68 & 128.2 & 40.34 & 49.42 & 64.44 & 144.98 & 198.88 & 297.56 & $8-400$ \\
\hline Co & 0.57 & 1.29 & 7.34 & 0.19 & 0.42 & 3.06 & 2.56 & 3.02 & 5.26 & $15-50$ \\
\hline $\mathrm{Se}$ & 3.07 & 5.37 & 17.91 & 1.57 & 5.96 & 8.27 & 5.49 & 9.64 & 15.08 & --- \\
\hline $\mathrm{Pb}$ & 9.42 & 17.76 & 54.95 & 8.12 & 32.7 & 52.8 & 9.60 & 41.5 & 73.06 & $0.1-10$ \\
\hline
\end{tabular}


of exposing to grow these (Table III, IV). The present finding lies within the normal range in plant material (Pendias, 1984). The concentration of $\mathrm{Cd}$ was recorded 0.28 and 0.42 ppm, respectively in plant sample when $E$. crassipes and $S$. cucullata were grown in $100 \%$ effluent water and the plants died within 6-7 and 7-8 days, respectively of exposures (Table III, IV). These values was comparatively high than the value of plants grown in 50\% and control water and was within the normal range in plant material (Pendias, 1984).

The concentration of $\mathrm{Cu}$ was recorded 22.05, 45.2 and 64.32 ppm, respectively in plant sample when $P$. stratiotes was grown in control water, $50 \%$ and $100 \%$ effluent water, which were within the normal range in plant material (Pendias, 1984) but the survival time of the plants decreased with raising the \% application of effluents from textile industries (Table III, IV). When E. crassipes was grown in $50 \%$ and $100 \%$ effluent water, the concentration of $\mathrm{Cu} 23.88$ and $27.72 \mathrm{ppm}$, respectively were found in its plant sample, which lie within the normal range in plant material (Pendias, 1984) but differ on the basis of percent concentration of effluent water. When S. cucullata was grown in $50 \%$ and $100 \%$ effluent, the concentration of $\mathrm{Cu}$ in plant analysis, were monitored i.e., 42.21 and $52.02 \mathrm{ppm}$, respectively which showed similarity with the normal range in plant material (Pendias, 1984) but was comparatively high than the plant samples grown in control culture (Table III).

When $50 \%$ and $100 \%$ effluent were applied on Pistia stratiotes the concentration of Li were recorded 7.41 and 9.52 ppm, respectively which were higher than the plant sample grown in control culture. The concentration of $\mathrm{Li}$ was recorded 1.94 and $2.81 \mathrm{ppm}$, respectively when Eichornia crassipes was grown in $50 \%$ and $100 \%$ effluent water. The content of Li was highest (21.36 ppm) in Salvinia cucullata when it was grown in $100 \%$ effluent water. Salvinia cucullata could uptake higher amount of Li compared to Pistia stratiotes and Eichornia crassipes (Table III).

In Pistia stratiotes, the concentration of Ni were found to be 5.86 and $8.32 \mathrm{ppm}$ after application of $50 \%$ and $100 \%$ effluent water, respectively. When Eichornia crassipes was grown in $50 \%$ and $100 \%$ effluent water the concentration of
Ni were recorded 3.9 and $4.92 \mathrm{ppm}$, respectively which bore similarity with the normal range in plant material (Pendias, 1984) but the value was higher in sample growing in higher percentage of effluent. After exposed to $50 \%$ and $100 \%$ effluent water, the concentration of Ni in Salvinia cucullata were found to be 8.27 and $15.35 \mathrm{ppm}$, respectively which exceeded the normal range in plant material (Pendias, 1984). This result showed that Salvinia cucullata could uptake higher amount of Ni compared to Pistia stratiotes and Eichornia crassipes (Table III).

Pistia stratiotes survived 7-9 and 2-3 days, respectively after application of $50 \%$ and $100 \%$ effluent (Table IV). Then the concentrations of $\mathrm{Zn}$ were recorded 64.68 and $128.2 \mathrm{ppm}$, respectively which was higher than the plants sample (47.1 ppm) grown in control culture but the results bears similarity with the normal range in plant material (Pendias, 1984) (Table III). When Eichornia crassipes was grown in 50\% and $100 \%$ effluent water, the concentration of $\mathrm{Zn} 49.42$ and $64.44 \mathrm{ppm}$, respectively were analysed to its plant sample, which also show the similar result with the normal range in plant material (Pendias, 1984). Salvinia cucullata (144.98 ppm) contain higher amount of Zn compared to Pistia stratiotes (47.1 ppm) and Eichornia crassipes (40.34 ppm) when grown in effluent free water (Table III). When Salvinia cucullata was exposed to $50 \%$ and $100 \%$ effluent water the concentration of $\mathrm{Zn}$ were found to be 198.88 and 297.56 ppm, respectively in its plant sample which was comparatively high than the other two plants (Pistia stratiotes and Eichornia crassipes) grown in same percentage of effluent (Table III).

When Pistia stratiotes was grown in effluent free water, 50\% and $100 \%$ effluent water, the concentration of Co were recorded $0.57,1.29$ and $7.34 \mathrm{ppm}$, respectively, in plant sample which values lay within the normal range in plant material (Pendias, 1984). The concentration of Co was found higher when Eichornia crassipes was grown in 100\% effluent (3.06 ppm) compared to the plant sample when grown in $50 \%$ effluent water $(0.42 \mathrm{ppm})$. The concentration of Co in all plants at both concentrations lay within the normal range in plant material (Pendias, 1984). When Pistia stratiotes, Eichornia crassipes and Salvinia cucullata were grown in

Table IV. Average times (days) required for survival of Eichornia crassipes, Pistia stratoites and Salvinia cucullata using $50 \%$ and $100 \%$ of effluents from textile industries

\begin{tabular}{lccc}
\hline$\%$ of effluent & $\begin{array}{c}\text { Time required for survival } \\
\text { of Pistia stratoites (days) }\end{array}$ & $\begin{array}{c}\text { Time required for survival of } \\
\text { Eichornia crassipes (days) }\end{array}$ & $\begin{array}{c}\text { Time required for survival of } \\
\text { Salvinia cucullata (days) }\end{array}$ \\
\hline 100 & $2-3$ & $6-7$ & $7-8$ \\
50 & $7-9$ & $17-20$ & $22-25$ \\
0 (Control) & Survive till to death & Survive till to death & Survive till to death \\
\hline
\end{tabular}


$100 \%$ effluent water, then the highest concentration of Co was recorded in Pistia stratiotes (7.34 ppm) which indicate that Pistia stratiotes can uptake higher concentration of Co compared to Eichornia crassipes and Salvinia cucullata. ity varied depending on the kind of metals and on species of plant absorbing the metal. Salvinia cucullata can uptake highest amount of $\mathrm{Cr}(75 \%)$ compared to other two species when cultured at $100 \%$ effluent. Both Eichornia crassipes

Table V. Comparison of \% uptake of metals by Eichornia crassipes, Pistia stratoites and Salvinia cucullata grown in $50 \%$ and $100 \%$ of effluent water in relation to control culture

\begin{tabular}{|c|c|c|c|c|c|c|}
\hline Metals & $\begin{array}{l}\% \text { of uptake by } \\
\text { Pistia stratiotes } \\
\text { L. from } 50 \% \\
\text { effluents }\end{array}$ & $\begin{array}{l}\% \text { of uptake by } \\
\text { Pistia stratiotes } \\
\text { L. from } 100 \% \\
\text { effluents }\end{array}$ & $\begin{array}{c}\% \text { of uptake by } \\
\text { Eichornia crassipes } \\
\text { M. from } 50 \% \\
\text { effluents }\end{array}$ & $\begin{array}{c}\% \text { of uptake by } \\
\text { Eichornia crassipes } \\
\text { M. from } 100 \% \\
\text { effluents }\end{array}$ & $\begin{array}{l}\% \text { of uptake by } \\
\text { Salvinia cuculla- } \\
\text { ta } \text { R. from } 50 \% \\
\text { effluents }\end{array}$ & $\begin{array}{c}\% \text { of uptake by } \\
\text { Salvinia cuculla- } \\
\text { ta R. from } 100 \\
\% \text { effluents }\end{array}$ \\
\hline $\mathrm{Cr}$ & 23 & 59 & 41 & 46 & 28 & 75 \\
\hline $\mathrm{Cd}$ & 33 & 41 & 29 & 57 & 50 & 62 \\
\hline $\mathrm{Cu}$ & 51 & 66 & 23 & 34 & 35 & 47 \\
\hline $\mathrm{Li}$ & 49 & 60 & 29 & 51 & 74 & 88 \\
\hline $\mathrm{Ni}$ & 8 & 35 & 2 & 23 & 42 & 69 \\
\hline $\mathrm{Zn}$ & 27 & 63 & 18 & 37 & 27 & 51 \\
\hline $\mathrm{Co}$ & 56 & 92 & 55 & 94 & 15 & 51 \\
\hline $\mathrm{Se}$ & 43 & 83 & 74 & 81 & 43 & 64 \\
\hline $\mathrm{Pb}$ & 47 & 83 & 75 & 85 & 76 & 86 \\
\hline
\end{tabular}

When $P$. stratiotes was grown in $50 \%$ and $100 \%$ effluent water, the concentration of Se recorded were 5.37 and 17.91 ppm, respectively in plant sample, which was higher than the plant sample grown in effluent free water. The concentration of Se was found 5.96 and $8.27 \mathrm{ppm}$, repectively, when Eichornia crassipes was exposed to $50 \%$ and $100 \%$ effluent water. In all cases the value of Se recorded lower in control sample and increased gradually with percent application of effluent. Pistia stratiotes (17.91 ppm) can uptake higher amount of Se compared to Eichornia crassipes (8.27 ppm) and Salvinia cucullata (15.08 ppm) after application of $100 \%$ effluent water.

When Pistia stratiotes, Eichornia crassipes and Salvinia cucullata were grown in 50\% effluent water, the concentration of $\mathrm{Pb}$ were found 17.76, 32.7 and $41.5 \mathrm{ppm}$, respectively which exceeded the normal range in plant material (Pendias, 1984). The concentration of $\mathrm{Pb}$ was recorded 54.95, 52.8 and 73.06 ppm, respectively when Pistia stratiotes, Eichornia crassipes and Salvinia cucullata were exposed to $100 \%$ effluent water which was much higher than the normal range in plant material (Pendias, 1984). In the control sample, the content of $\mathrm{Pb}$ bears similarity with normal range in plant material (Pendias, 1984).

Eichornia crassipes, Pistia stratoites and Salvinia cucullata are capable of removing metals from textile-dyeing effluents. It is clear that the uptake of metals increased after application of higher percentage of effluent but the uptake capac- and Pistia stratoites shows great potential in removing Co (>90\%), Se (>80\%) and $\mathrm{Pb}(>80 \%)$ while grown in $100 \%$ effluent water. When cultured in more concentrated effluent, individually Salvinia cucullata shows highest potential in absorbing $\mathrm{Cr}, \mathrm{Cd}, \mathrm{Li}, \mathrm{Ni}$ and $\mathrm{Pb}$; while Pistia stratoites shows potential in absorbing $\mathrm{Cu}, \mathrm{Zn}$ and Eichornia crassipes is more suitable in absorbing $\mathrm{Co}$ and $\mathrm{Pb}$.

The uptake of $\mathrm{Cr}, \mathrm{Cd}, \mathrm{Cu}, \mathrm{Li}, \mathrm{Ni}, \mathrm{Zn}, \mathrm{Co}, \mathrm{Se}$ and $\mathrm{Pb}$ by Eichornia crassipes, Pistia stratoites and Salvinia cucullata were relatively high when exposed to $50 \%$ effluent, but highest values were obtained after application of $100 \%$ effluent. It may, therefore, be concluded that there is a direct relationship between percentages of effluent concentrations and uptake of metals by Eichornia crassipes, Pistia stratoites and Salvinia cucullata. But the survival time gradually decreased with increasing the percentage of effluent.

\section{Conclusion}

Metal pollution is a problem associated with areas of intensive industry. The recorded $\mathrm{pH}, \mathrm{EC}, \mathrm{BOD}, \mathrm{TSS}$, TDS, Turbidity and TOC were quite higher in the industrial effluent and crossed the recommended values of DOE. DO value also much lower than the limit of DOE. This is the sole cause for low survival time of aquatic life. So when Eichornia crassipes, Pistia stratoites and Salvinia cucullata were exposed to $100 \%$ of effluents, they survived only for a few days. The content of metals of industrial effluent, like $\mathrm{Cr}$, Se, 
$\mathrm{Pb}$ and $\mathrm{Cu}$ were exceeded the permissible limit and other metals such as $\mathrm{Cd}, \mathrm{Li}, \mathrm{Ni}$ and $\mathrm{Zn}$ were within the limit but were much higher in the effluent water compared to control water. Metals occur naturally in the plant; however concentrations are greatly increased when they are exposed to higher concentrated industrial effluent. This may be due to phytoextraction or hyper-accumulation metals by the plant species. From the results, it is clear that all studied hydrophytes are capable of uptake metals but the uptake capacity is totally depend on type of metal and species of plant used. Both Pistia stratoites and Eichornia crassipes can be used with a greater advantage in removing $\mathrm{Co}$, Se and $\mathrm{Pb}$ from effluent water to enhance surface water treatment system. Individually Salvinia cucullata (at 100\% effluent water) can uptake higher amount of $\mathrm{Cr}, \mathrm{Cd}, \mathrm{Li}$ and $\mathrm{Pb}$ compared to other two plant species from metal polluted water in order to enhance water quality.

\section{References}

Abbasi SA and Nipaney PC (1993), World's worst weedcontrol and utilization. International Book Distributors, Dehra Dun. p. 226.

Akcin G, Harazon E and Hellier DE (1994), Removal of lead by water hyacinth, J. Environ. Sci. and Health, 29 (40): 2177-2183.

APHA (1976), Standard methods for the examination of water and wastewater (14th ed). American Public Health Association, Washington. 1193.

Chow TJ (1968), Water Pollution Control Federation, UK, 40, pp 399-411.

Dara SS (2002), A Textbook of Environm- ental Chemistry and Pollution Control. S. Chand and Company Limited, New Delhi, India. pp 24-30.

Davis ML and Cornwell DA (1998), Introduction to Environmental Engineering. WCB/McGraw-Hill Book Co., Singapore. pp 469-535.

De AK (2000), Environmental Chemistry. 4th Ed. New Age International P. limited, New Delhi. pp 2-4, 269.

DOE (Department of Environment). (2003), A Compilation of Environmental Laws of Bangladesh. pp 212-214.

Emongor VK, Ealotswe E, Koorapetse I, Sarihvasa S and Keikanetswe S (2005), Pollution indicators in Gaberone effluent, J. Appl. Sci. 5: 147-150.

Espinoza - Quinones FR, Zacarkim C E, Palacio SM, Obreg' on CL, Zenatti DCR, Galante M. and Rizzuto MA (2004), Removal of heavy metals from polluted river water using aquatic macrophytes Salvinia spp. Instituto de F'isica, Universidade.

Goutam A (1992), Aquatic Environment, Ashis Publishing House, New Delhi. Gurna, C.F. 165. Industrial Work Control, Academic Press New York. pp.112-117.

Gupta PK (2005), Methods in Environmental Analysis: water, soil and air. Agrobios Jodhpur, India. pp 13-73.

Hossain MA (2010), Removal of ammonia pollution from surface water by nitrification and aquatic macrophytes. Ph.D. Thesis, Department of Microbiology, University of Dhaka, Bangladesh.

Kabir SE, Kabir M, Mia C.M, Begum N, Chowdhury D, Sultana MS and Rahman MS (2002), Assessment of Effluent Quality of Dhaka Export Processing Zone with special Emphasis to that of the Textile and Dyeing Industries; Jahangirnag. Univer. J. of Scien. 25: $137-145$.

Moore M, McLeod K and Reed D (1960), Fisheries: Conservation, propagation and regulation, Washington Department of Fisheries, USA. pp. 155-163.

Peavy HS, Rowe DRR and Tehobanoglous G (1985), Environmental Engineering. McGraw-Hill Book Company, NY, USA. pp 417-461.

Pelczer MJ, Chan ECS and Krieg NR (1993), Microbiology: Concepts and Application. 2nd ed. Mcgraw Inc.

Pendias (1984), Trace elements in soils and plants, 2nd ed., 19, London CRC press.

Rouse RD (1979), Water quality management in pond fish culture. In: Research and Development Series No. 22, Project: AID/DSAN-G 0039, Auburn University, Alabama, USA.

Russel A (1987), Guinness Book of World Records. Bantam Books, New York. 105.

Salati E (1987), Edaphic-phytodepuration: A new approach to wastewater treatment. In K. R. Reddy \& W. H. Smith (Eds.), Aquatic plants for water treatment and resource recovery, Orlando Fl: Magnolia. pp. 199-208.

Sultana MS, Rahman MM, Alam AKMR, Saadat AHM and Uddin MJ (2003), Analysis of some trace elements in the uncultivated soils of Savar by ICPMS, Bangladesh Journal of Environmental Science, 1: 57-62.

Yusuff RO, Sonibare JA (2005), Characterization of textile industrial effluents in Kaduna, Nigeria and pollution implications. Global Nest: the Int. J. 6 (3): 212-221

Received: 07 August 2012; Revised: 16 April 2013, Accepted: 08 May 2013. 